\title{
Primary intratesticular leiomyosarcoma
}

\author{
Shunsuke Yoshimine, MD; ${ }^{*}$, Hidaka Kono, MD; ${ }^{*}$ Ken Nakagawa, MD; ${ }^{*}$ Eiji Kikuchi, MD; ${ }^{*}$ Akira Miyajima, MD;* \\ Kaori Kameyama, MD; ${ }^{\dagger}$ Makio Mukai, MD; ${ }^{\dagger}$ Mototsugu Oya, MD*
}

\begin{abstract}
This report presents a case of primary intratesticular leiomyosarcoma. A 73-year-old male presented with a 6-year history of left scrotal swelling. A radiological examination revealed a left testicular tumour with multiple metastases in the lung, para-aortic lymph node and other organs. A radical orchiectomy was carried out and the pathology revealed an intratesticular leiomyosarcoma. The patient received additional chemotherapy. Cases of primary intratesticular leiomyosarcoma are rare. This is, to the best of our knowledge, only the tenth case of leiomyisaocoma in an adult reported in the literature, and the first case involving multiple metastases.
\end{abstract}

Can Urol Assoc J 2009;3(6):E74-E76

\section{Introduction}

Leiomyosarcomas are malignant soft-tissue tumours arising from any tissues containing smooth muscles. However, cases arising in testicular tissue are extremely rare and only 9 cases in adults have been reported so far. Metastatic patients have not been reported. This report presents the first case of an intratesticular leiomyosarcoma with multiple metastases.

\section{Case Report}

A 73-year-old male patient visited our hospital with a 6 -year history of a left scrotal mass. He had no significant past medical history. A physical examination revealed a left scrotal mass and several palpable subcutaneous nodules ranging from $1 \mathrm{~cm}$ to $4 \mathrm{~cm}$ in diameter on the chest and abdomen, suggesting subcutaneous metastatic lesions. Lactate dehydrogenase (LDH) and $\alpha$-fetoprotein (AFP) levels were within the normal ranges, whereas human chorionic gonadotropin- $\beta$ (HCG- $\beta$ ) was slightly elevated at 0.3 $\mathrm{ng} / \mathrm{mL}$ (normal range: $<0.1 \mathrm{ng} / \mathrm{mL}$ ). An ultrasonographic examination of the left testis showed a solid mass with hypoechoic and hyperechoic components. Computed tomography scan revealed a left scrotal mass (Fig. 1a), and metas- tases to the lung (Fig. 1b), para-aortic lymph node, spleen, muscle, subcutaneous tissue and vertebral bone.

The patient underwent a left radical orchiectomy. Macroscopically, the tumour was a well-encapsulated whitish to yellowish solid mass with hemorrhage and necrosis (Fig. 2). There was no invasion to the spermatic cord or tunica vaginalis. The weight of the tumour was $1570 \mathrm{~g}$ and the size was approximately $20 \times 18 \times 14 \mathrm{~cm}$. Microscopic examination showed a high degree of cellular proliferation composed of spindle cells with round or oval-shaped nuclei implicating a storiform growth pattern (Fig. 3a). There were more than 2 mitoses per high-power field. Necrosis was evident. Some marked pleomorphic tumour cells with multinucleated giant cells were observed. Immunohistochemical examination revealed that the tumour cells were strongly positive for smooth muscle actin and desmin (Fig. 3b), but negative for S-100 and myogenic regulatory protein (MyoD1) proteins. The pathological diagnosis was leiomyosarcoma.

The patient received additional CYVADIC (cyclophosphamide, vincristine, adriamycin, dacarvazine) chemotherapy. There was no progression of the metastatic lesions as of 9 months after the operation.

\section{Discussion}

Intratesticular leiomyosarcoma is an extremely rare tumour and only 9 cases have been reported in adults (Table 1). ${ }^{1-8}$ Only one case was reported in an infant. ${ }^{9}$ The age of the patients ranged between 30 and 76, with a mean age of 50.2. Six patients had a right-side tumour, while 3 had a left-side tumour. A radical orchiectomy was carried out in all patients, while one patient underwent an orchiectomy and a retroperitoneal lymph node dissection that revealed a negative lymph node. One patient died of lung metastasis 14 months after the orchiectomy.

All of these cases were assessed as clinical stage-I tumours, as all of the testicular leiomyosarcomas were diagnosed as a local disease, easily recognized and slow-growing. Based on these findings, no adjuvant treatment was administered in these patients. ${ }^{8}$ Eight patients achieved tumour-free survival 

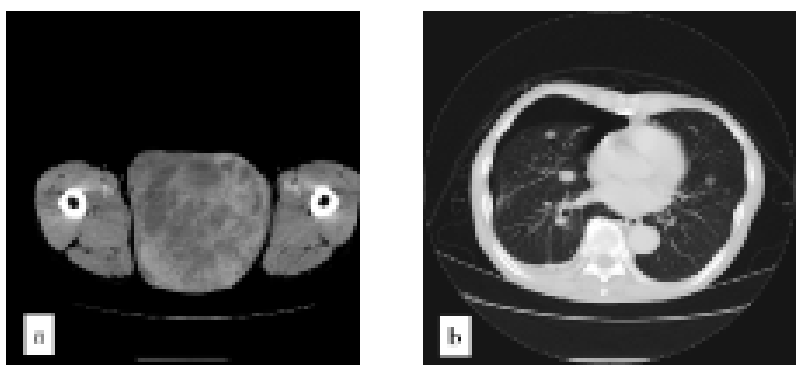

Fig. 1. a: Contrast-enhanced computed tomography (CT) scan of the mass developing in left scrotum. b: Chest CT scan shows multiple lung nodules with left pneumothorax.

during the course of observation. Therefore, it is still controversial as to whether adjuvant therapy is needed for such cases.

The true etiology of testicular leiomyosarcoma is unknown; however, risk factors have been reported in 3 patients: the use of high-dose anabolic steroids (Case 5), ${ }^{4}$ chronic inflammation of the testis (Case 7$)^{5}$ and testicular field radiation for the treatment of leukemia (Case 9). ${ }^{7}$

The present case was the first case assessed as clinical stage-III. The patient had no obvious past medical history or risk factors; however, it is possible that the metastases had progressed because the testicular tumour had been left untreated for 6 years.

All the tumour markers (AFP, HCG- $\beta$ and LDH) used in the previously reported cases were within the normal range. In the present case, HCG- $\beta$ was slightly elevated to $0.3 \mathrm{ng} / \mathrm{mL}$ before the operation. Metastatic tumours persisted in several organs in our patient; nonetheless, HCG- $\beta$ was normalized after the operation. The validity of these 3 tumour markers for testicular leiomyosarcoma, in particular for the evaluation of metastatic disease, is limited.

Based on a review of the literature, the treatment for an intratesticular leiomyosarcoma is a radical orchiectomy and surveillance followed by radiological examination in cases at stage-I. There are no available data regarding the

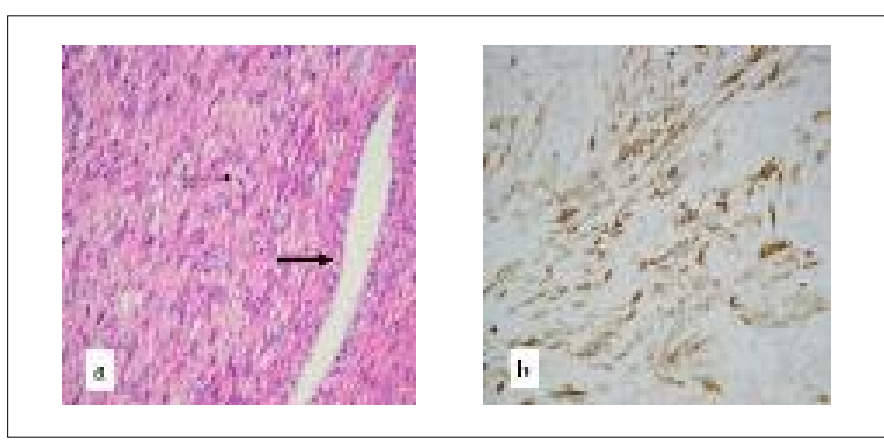

Fig. 3. Microscopic image of the intratesticular leiomyosarcoma. a: The image shows fasciculated spindle cells with a small nucleus of mitosis (thin black arrow). Epididymis was involved in the tumour cells (fat black arrow). H. E. stain. $(\times 100)$. b: The tumour cells were positive for desmin stain. $(\times 100)$.

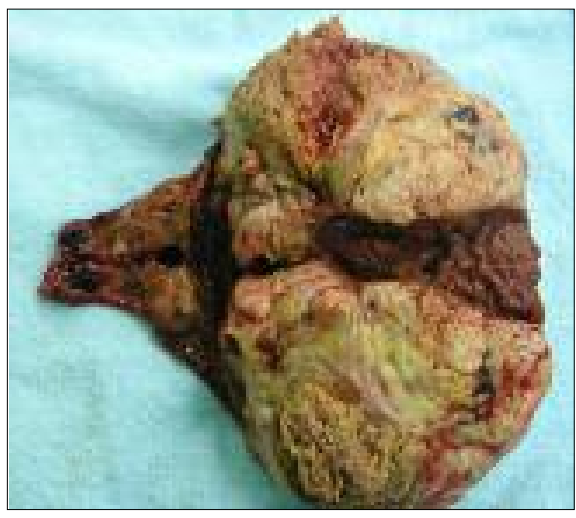

Fig. 2. Macroscopically, the tumour was yellowish and contained solid and necrotic compartments.

management of stage-II or stage-III tumours. Radiation therapy is not effective for a leiomyosarcoma; therefore, additional chemotherapy is required in advanced cases.

Recently, either gemcitabine or docetaxel has been used as chemotherapy for metastatic uterine leiomyosarcomas, with high objective response rates. ${ }^{10}$ In the urological field, it is necessary to consider the use of new agents for a metastatic testicular leiomyosarcoma. Taken together, further clinical investigation is required for establishing treatment for an intratesticular leiomyosarcoma.

\section{Conclusion}

We experienced an extremely rare case of stage-III primary intratesticular leiomyosarcoma in which a left radical orchiectomy was performed and additional chemotherapy was administered to the metastatic lesions.

*From the Department of Urology; ${ }^{\dagger}$ Division of Diagnostic Pathology, Keio University School of Medicine, Tokyo, Japan

Competing interests: None declared.

This paper has been peer-reviewed.

\section{References}

1. Yachia D, Auslaender L. Primary leiomyosarcoma of the testis. J Urol 1989;141:955-6.

2. Pellice C, Sabate M, Combalia A, et al. Leiomyosarcoma of the testis. J Urol (Paris) 1994;100:46-8.

3. Washecka RM, Mariani AJ, Zuna RE, et al. Primary intratesticular sarcoma. Immunohistochemical ultrastructural and DNA flow cytometric study of three cases with a review of the literature. Cancer 1996;77: 1524-8.

4. Froehner $M$, Fischer $R$, Leike $S$, et al. Intratesticular leiomyosarcoma in a young man after high dose doping with Oral-Turinabol: a case report. Cancer 1999;86:1571-5.

5. Ali Y, Kehinde EO, Makar R, et al. Leiomyosarcoma complicating chronic inflammation of the testis. Med Princ Pract 2002;11:157-60.

6. Hachi H, Bougtab A, Amhaiji R, et al. A case report of testicular leiomyosarcoma. Med Trop (Mars) 2002;62:531-3.

7. Canales BK, Lukasewycz SJ, Manivel JC, et al. Postradiotherapy intratesticular leiomyosarcoma. Urology 2005;66:657. 
Yoshimine et al.

Table 1. Summary of the 9 published case reports

\begin{tabular}{|c|c|c|c|c|c|c|c|c|c|}
\hline $\begin{array}{c}\text { Case } \\
\text { no. }\end{array}$ & Authors & Age & Side & $\begin{array}{l}\text { Clinical } \\
\text { stage }\end{array}$ & Treatment & $\begin{array}{l}\text { Follow-up } \\
\text { (months) }\end{array}$ & Outcome & $\begin{array}{c}\text { Risk } \\
\text { factors }\end{array}$ & $\begin{array}{l}\text { Levels of } \\
\text { tumour } \\
\text { markers }\end{array}$ \\
\hline 1 & Yachida ${ }^{1}$ & 55 & $\mathrm{R}$ & I & orchiectomy & 24 & survived & - & normal \\
\hline 2 & Pellice $^{2}$ & 37 & L & 1 & orchiectomy & 24 & survived & - & normal \\
\hline 3 & Washecka $^{3}$ & 47 & $\mathrm{R}$ & I & orchiectomy & 49 & survived & - & normal \\
\hline 4 & Washecka $^{3}$ & 40 & $\mathrm{R}$ & I & orchiectomy & 42 & survived & - & normal \\
\hline 5 & Froehner $^{4}$ & 32 & $\mathrm{R}$ & I & $\begin{array}{c}\text { orchiectomy + } \\
\text { RPLND }\end{array}$ & 79 & survived & $\begin{array}{l}\text { anabolic } \\
\text { steroid }\end{array}$ & unknown \\
\hline 6 & $\mathrm{Hachi}^{6}$ & 70 & L & I & orchiectomy & 14 & $\begin{array}{l}\text { death (lung } \\
\text { metastases) }\end{array}$ & - & normal \\
\hline 7 & $\mathrm{Ali}^{5}$ & 65 & $\mathrm{R}$ & I & orchiectomy & 12 & survived & $\begin{array}{c}\text { chronic } \\
\text { inflammation }\end{array}$ & normal \\
\hline 8 & Takizawa $^{8}$ & 76 & L & I & orchiectomy & 12 & survived & - & normal \\
\hline \multirow[t]{2}{*}{9} & Canales $^{7}$ & 30 & $\mathrm{R}$ & 1 & orchiectomy & 6 & survived & radiation & unknown \\
\hline & Current case & 73 & L & III & $\begin{array}{l}\text { orchiectomy+ } \\
\text { chemotherapy }\end{array}$ & 9 & survived & - & slightly elevated \\
\hline
\end{tabular}

8. Takizawa A, Miura T, Fujinami K, et al. Primary testicular leiomyosarcoma. Int J Urol 2005;12:596-8.

9. Wakhlu A, Chaudhary A. Massive leiomyosarcoma of the testis in an infant. J Pediatr Surg 2004;39: e16-7.

10. Hensley ML, Blessing JA, Mannel R, et al. Fixed-dose rate gemcitabine plus docetaxel as first-line therapy for metastatic uterine leiomyosarcoma: a Gynecologic Oncology Group phase II trial. Gynecol Oncol 2008; 109:329-34
Correspondence: Dr. Hidaka Kono, Department of Urology, Keio University School of Medicine, 35 Shinnomomachi, Shinjuku-ku, Tokyo 160-8582, Japan; fax: 81-3-3225-1985; yuho@kde.biglobe.ne.jp 